\section{Mechanisms of Coal-Water Mixture Combustion in Fluidized Beds}

\section{Technical Progress Report for the Period September 14, 1989 - December 15, 1989}

Robert C. Brown

Principal Investigator

Work Performed Under Grant

No. DE-FG22-87PC79915

For

U. S. Dept. of Energy

Pittsburgh Energy Technology Center

Pittsburgh, PA

By

Iowa State University

\section{DISCLAIMER}

Ames, IA 50011
This report was prepared as an account of work sponsored by an agency of the United States Government. Neither the United States Government nor any agency thereof, nor any of their employees, makes any warranty, express or implied, or assumes any legal liability or responsibility for the accuracy, completeness, or usefulness of any information, apparatus, product, or process disclosed, or represents that its use would not infringe privately owned rights. Reference herein to any specific commercial product, process, or service by trade name, trademark, manufacturer, or otherwise does not necessarily constitute or imply its endorsement, recommendation, or favoring by the United States Government or any agency thereof. The views and opinions of authors expressed herein do not necessarily state or reflect those of the United States Government or any agency thereof.
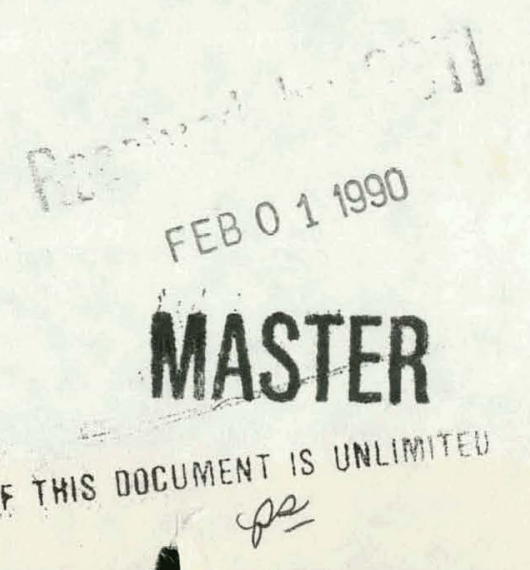

DISTRIBUFION OF THIS DOCUMENT IS UNLIMITEH 


\section{DISCLAIMER}

This report was prepared as an account of work sponsored by an agency of the United States Government. Neither the United States Government nor any agency Thereof, nor any of their employees, makes any warranty, express or implied, or assumes any legal liability or responsibility for the accuracy, completeness, or usefulness of any information, apparatus, product, or process disclosed, or represents that its use would not infringe privately owned rights. Reference herein to any specific commercial product, process, or service by trade name, trademark, manufacturer, or otherwise does not necessarily constitute or imply its endorsement, recommendation, or favoring by the United States Government or any agency thereof. The views and opinions of authors expressed herein do not necessarily state or reflect those of the United States Government or any agency thereof. 


\section{DISCLAIMER}

Portions of this document may be illegible in electronic image products. Images are produced from the best available original document. 
The first quarter of FY 1990 was used to correct problems described in the previous progress report and to initiate a series of experiments on calcination and sulfation of coal-water-limestone mixtures (CWLM) in fluidized beds.

Acid condensation

The failure of an acid mist filter and Perma-Pure drier in the previous quarter made us sensitive to the possible occurrence of acid condensation in all of our experiments. To evaluate this possiblity, we disassembled the gas sampling system after each test to inspect for condensation. Despite an expected dewpoint temperature well below room temperature, we regularly discovered small quantities of liquid at the exit of the Perma-Pure drier where the lines were no longer heat traced. From previous experience we have learned that a desiccant such as Drierite cannot be used to eliminate this fugitive moisture: S02 is also removed by the desiccant. To prevent this corrosive liquid from entering gas analyzers located downstream, we installed a small impingement filter in the line. Although the condensate collected in the filter can also absorb S02 from the gas stream, the surface area for this gas-liquid reaction is rather limited in the filter. Furthermore, titration of this liquid allows us to quantify the amount of $\mathrm{S02}$ lost from the gas stream.

In practice, the amount of $\mathrm{S0} 2$ removed by condensate is negligibly small compared to the gas stream concentration. A typical CWM test ( $43 \%$ water) lasting 1.5 hrs yields only $3.2 \mathrm{ml}$ of condensate with a pH of 2 . Our calculations indicate that this represents a $0.0008 \%$ reduction in $\mathrm{S} 02$ concentration when burning CWM without sorbent and only a $0.003 \%$ reduction when burning CWM with sorbent. Accordingly, we can neglect this correction to $S 02$ readings. After this determination, we were confident to proceed with our calcination and sulfation tests.

\section{Calcination/Sulfation Tests}

Hypothesis: CWLM has better sorbent utilization than dry coal and limestone.

Some researchers $[1,2]$ suggest that addition of limestone directly to CWM can improve sorbent utilization compared to burning dry coal in a limestone bed. However, these two approaches to limestone addition have rarely been performed under comparable experimental conditions: observed differences might be attributable to differences in coals or combustion conditions used for the two methods of sorbent addition. Roberts et al. [3] have compared sorbent utilization for CWLM and dry limestone using identical feedstocks under the same combustion conditions. They found no differences in sorbent utilization. However, these tests were performed in a pressurized fluidized bed combustor which displays distinct desulfurization behavior [4] compared to atmospheric combustors of interest in our study.

Test: Coal and limestone were crushed separately in a hammermill fitted with a $1 / 16$ inch screen. The cumulative size distribution of the limestone is given in Table 1. These were blended in proportions to give a $\mathrm{Ca} / \mathrm{S}$ ratio of 2.0 with added water sufficient to give a solids loading of $57 \%$. The resulting CWLM was burned in a six-inch deep sand bed at $1505 \mathrm{~F}$.

Two dry sorbent tests were performed using $3 / 8$ inch $\times 8$ mesh dry coal to fire the combustor, Both dry sorbents were injected directly into a six-inch deep 
sand bed using the pneumatic conveyance system described in a previous quarterly report. The first dry sorbent was the same crushed limestone used to prepare CWLM. We estimated that particles injected into the bed finer than $200 \mathrm{~m}$ would elutriate from the bed before they could significantly participate in desulfurization. This fine limestone was tested at a bed temperature of $1518 \mathrm{~F}$.

A coarse limestone was prepared by double screening the product of a roller mill to 18 mesh $\times 35$ mesh. The cumulative size distribution for this coarse limestone is compared to the fine limestone distribution in Table 1 . We estimate that $99 \%$ of this material will not elutriate from the bed until significant attrition occurs. The coarse limestone test was performed at $1498 \mathrm{~F}$.

Results: Fig 1. displays the results of these tests. The S02 reduction of $65 \%$ for the CWLM is significantly better than the $40 \%$ reduction obtained with the fine limestone. However, the $60 \%$ reduction obtained with the coarse limestone is comparable to the CWLM. These results suggest that fine limestone is trapped in CWLM agglomerates long enough to influence desulfurization. However, no advantage is indicated for CWLM compared to coarsely ground limestone when the bed is operated at $1500 \mathrm{~F}$.

Hypothesis: Both calcination and sulfation occur within CWLM agglomerates.

The previous results clearly indicate some influence of agglomerate formation on desulfurization. Our previous work has shown that agglomerate residence time is only on the order of one minute [5]. It is not evident whether this is sufficient time for both calcination and sulfation to occur within the agglomerate or whether the environment within the agglomerate is favorable for both processes to occur.

Test: Basu [6] has shown that coal particles burn at temperatures as much as $360 \mathrm{~F}$ higher than the surrounding bed, depending on the size of the coal particles. Furthermore, it is well known that an optimal temperature (about $1550 \mathrm{~F}$ ) exists for limestone utilization. This maxima occurs because both the extent of calcination and the rate of sulfation increase with temperature. Eventually a temperature is reached at which 502 reacts to form calcium sulfate before it can deeply penetrate the pores formed by calcination. Sulfate blocks the pores to additional S02 penetration and limestone utilization is reduced despite the favorable thermodynamics for calcination at elevated temperatures.

Mei et al. [7] were the first to suggest that sorbent utilization might be degraded if limestone is incorporated into CWM that is burned at conventional FBC temperatures. They reasoned that the the limestone will calcine and sulfate at the temperature of the burning CWLM agglomerate rather than at the lower bed temperature. If this is indeed the case, we should be able to show that the optimum temperature for desulfurization when burning CWLM in a sand bed should be significantly below the optimum temperature for dry coal burned in a limestone bed. The hypothesis was tested by repeating the experiments performed for the first hypothesis over a range of temperatures.

Results: Data is presented in Fig. 2 as percent reduction in $\mathrm{SO} 2$ as a function of temperature. No discernable peak emerges for the fine limestone when 
burning dry coal although this result may simply reflect the scarcity of data around $1550 \mathrm{~F}$ where the peak is expected. By contrast, the data for CWM with added fine limestone clearly peaks at $1460 \mathrm{~F}$, nearly $100 \mathrm{~F}$ lower than expected for combustion of dry coal in limestone beds. A similar comparison between CWM with added fine limestone and dry coal with coarse limestone injected separately is given in Fig. 3. The coarse limestone data shows a broad peak between 1500 and $1550 \mathrm{~F}$. Furthermore, it appears that the dry coal burned with coarse limestone will have better sorbent utilization than the CWLM at temperatures above about $1525 \mathrm{~F}$.

We repeated these tests for CWLM with a $\mathrm{Ca} / \mathrm{S}$ ratio of 1.0 . These results are in Fig. 4. The location of the peak is difficult to discern for the limited data, but clearly the optimal temperature is below $1460 \mathrm{~F}$. We conclude that there is good evidence that both calcination and sulfation occur within the agglomerate.

Test: An additional test of the previous hypothesis is to recover CWLM agglomerates from the fluidized bed and subject them to chemical analysis. If significant calcination and sulfation occur in agglomerates, we should detect $\mathrm{CaO}$ and $\mathrm{CaSO} 4$ in addition to carbonate. Agglomerates can be recovered by the quench test described in previous progress reports. We have performed such a test but have not yet analyzed the agglomerates.

We must yet answer why the maximum S02 capture for CWLM is greater than the maxima for either fine or coarse limestone injected dry into a sand bed. Several possibilities are under investigation.

Hypothesis: The intimate contact of coal and limestone in the agglomerate is responsible for the improved utilization.

Test: CWLM and coal-limestone briquettes should show comparable limestone utilization. These tests are in progress.

Hypothesis: The gasification environment of a fluidized bed burning CWLM favors more complete calcination.

Th1s hyputhesis is bascd on the premise that a gasification environment exists around the calcining limestone. Equilibrium calculations that treat the combustor as a well-stirred reactor doe not support this notion: sufficient oxygen exits to yield a very low partial pressure for $\mathrm{Co}$. However, the emulsion phase of a fluidized bed, in contrast to the bubble phase, may be substoichiometric during combustion [8]. Furthermore, several models of burning coal particles suggest that local concentrations of $C O$ can be very high [9]. Accordingly, high water vapor concentrations might promote the water-shift reaction:

$$
\mathrm{CO}+\mathrm{H} 2 \mathrm{O} \rightarrow \mathrm{CO} 2+\mathrm{H} 2
$$

and a gasification envixonment can be envisioned in either the emulsion phase or the boundary layer surrounding the burning agglomerates. We have not devised a method for directly testing for such localized gasification conditions. 
The high $\mathrm{CO} 2$ concentrations under gasification conditions will slow the calcination reaction

$$
\mathrm{CaCO} 3 \longrightarrow \mathrm{CaO}+\mathrm{CO} 2
$$

by shifting equilibrium to the left. Slower calcination might be expected to allow the rate of poor plugging by sulfation to overtake calcination, resulting in lower limestone utilization. However, two other processes may occur which reduce the net rate of sulfation under local gasification conditions. First, $\mathrm{H} 2$ and $\mathrm{CO}$ can decompose $\mathrm{CaSO}_{4}$ to $\mathrm{CaO}[10]$. Accordingly, calcination might proceed to completion before sulfation began to plug pores. Furthermore, under high partial pressures of $\mathrm{SO}_{2}$ or $\mathrm{H}_{2} \mathrm{~S}$, as might exist in burning agglomerates, $\mathrm{CaS}$ is the stable sorbent product $[10]$. The smaller molar volume of this solid compared to $\mathrm{CaSO}_{4}$ might avoid premature pore plugging. This compound is quickly converted to sulfate upon exposure to oxidizing conditions.

Test: We avoid fundamental questions as to the existence of local gasification conditions and the effects of such conditions on calcinations by simply evaluating the effect on water addition on sorbent utilization. Two tests will be performed. The first will inject water into the combustor when burning dry coal with dry limestone in a sand bed. This test will evaluate the importance of gasification conditions in the emulsion phase. The second test repeats the previous coal-limestone briquette tests but with water injected into the bed. This test will evaluate the importance of local gasification conditions around burning coal-limestone agglomerates (here simulated by briquettes).

Hypothesis: Increased residence time of fine sorbent is responsible for improved sorbent utilization observed in the first test we reported.

Test: Formulate CWLM with coarse limestone. If the hypothesis is true, peak S02 reduction should be the same as for dry coal burned with coarse limestone in a sand bed since residence times will be comparable. 


\section{References}

1. Trivett, G. S., Field, R. S. and MacKay, G. D. "Coal-limestone-water slurry testing in atmospheric fluidized-bed combustion," Proc. 8 th Int. Conf. on FBC, 1985 , pp. 948-961.

2. Cen, K., Cao, X., Yval, Z., Hang, S., Hie, J., Lu, M., Ni, M., Chen, Y. "Combustion and gasification of coal-water slurry in fluidized beds," Proc. 7th Int. Conf. on FBC, Philadelphia, PA, 1982, pp. 253-163.

3. Roberts, A., Philai, K., Barker, S., and Carpenter, L. "Combustion of 'Run-of-Mine' coal and coal-water mixtures in small PFBC, Proc. 7 th Int. Conf. in FBC, Philadelphia, PA, 1982, pp. 482-489.

4. Brown, R. C. "Pollution control in fluidized bed combustion," in Fossil Fuels Utilization: Environmental Concerns, R. Markuszewski and B. D. Blausteín, Eds., American Chemical Society, Washington, D.C., 1986, pp. 98-108.

5. Gregory, J. and R. C. Brown "Combustion behavior of coal-water mixtures in fluidized beds," Proc. 10th Int. Conf. on FBC, San Francisco, 1989, pp. 77-84.

6. Basu, P. "Burning rate of carbon in fluidized beds," Fuel 56, 390-392 (1977).

7. Mei, J. S., Cho, J. C., and Martin, D. "Fluidized bed combustion of coal-water fuels: microstructural characteristics of char-agglomerates," Sixth Int. Meeting on coal-liquid and alternative fuels, Halifax, Nova Scotia, 1986.

8. Ljungström, E. B. "In-bed oxygen measurements in a commercial-size AFBC," Proc. 8th Int. Conf. on FBC, Houston, TX, 1985, pp. 853-864.

9. Essenhigh, R. H. "Fundamentals of Coal Combustion," in Chemistry of Coal Utilization, M. A. Elliott, Ed., Wiley, New York, 1981, pp. 1153-1312.

10. Lyngfelt, A. and leckner, B. "The effect of reductive decomposition of $\mathrm{CaSO}_{4}$ on sulfur capture in fluidized bed boilers," Proc. 10th Int. Conf. FBC, ${ }^{4}$ San Francisco, CA, 1989, pp. 675-684. 
Figure 1

COMPARATIVE FLOT FOR DRY COAL AND CMM $\sigma_{1}=1 / 2$

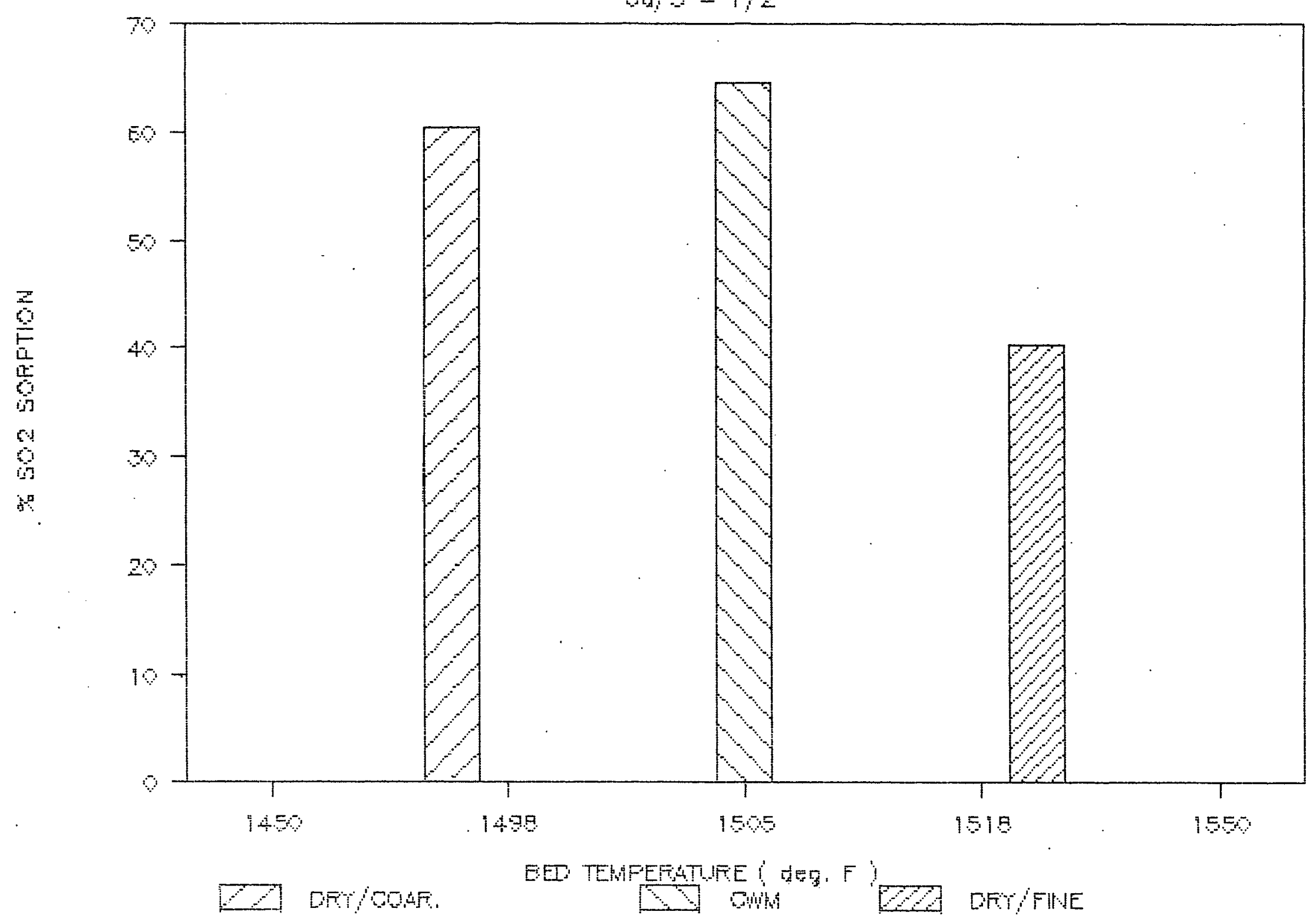


Figure $2 \%$ SULFUR SORPTION VS. BED TEMPERATURE

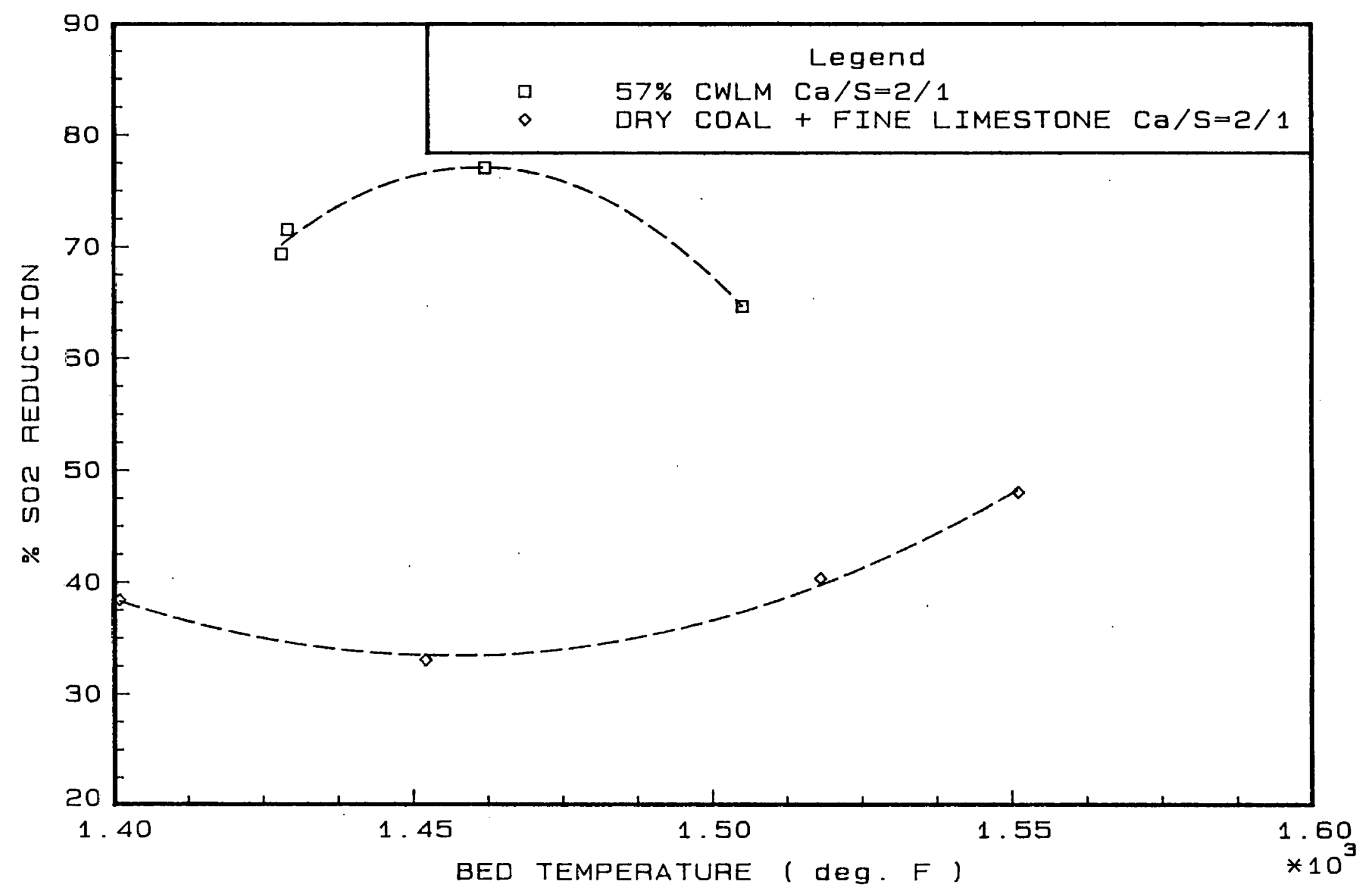


Figure $3 \%$ SOZ SORPTION Vs. BED TEMPERATURE

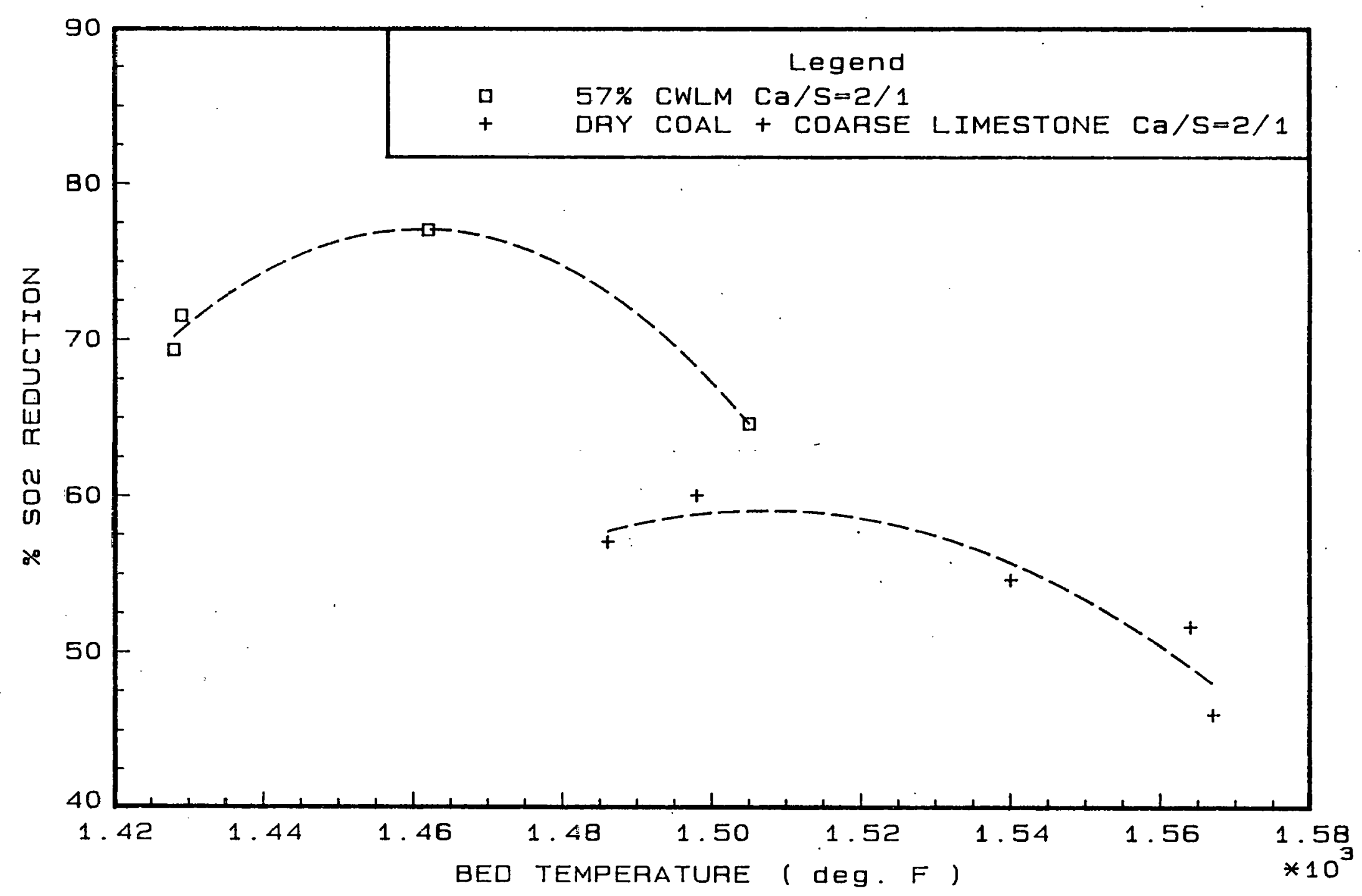


Figure $4 \%$ SULFUR SOAPTION VS. BED TEMPERATURE $\mathrm{Ca} / \mathrm{S}=2 / 1$ : COARSE SORBENT

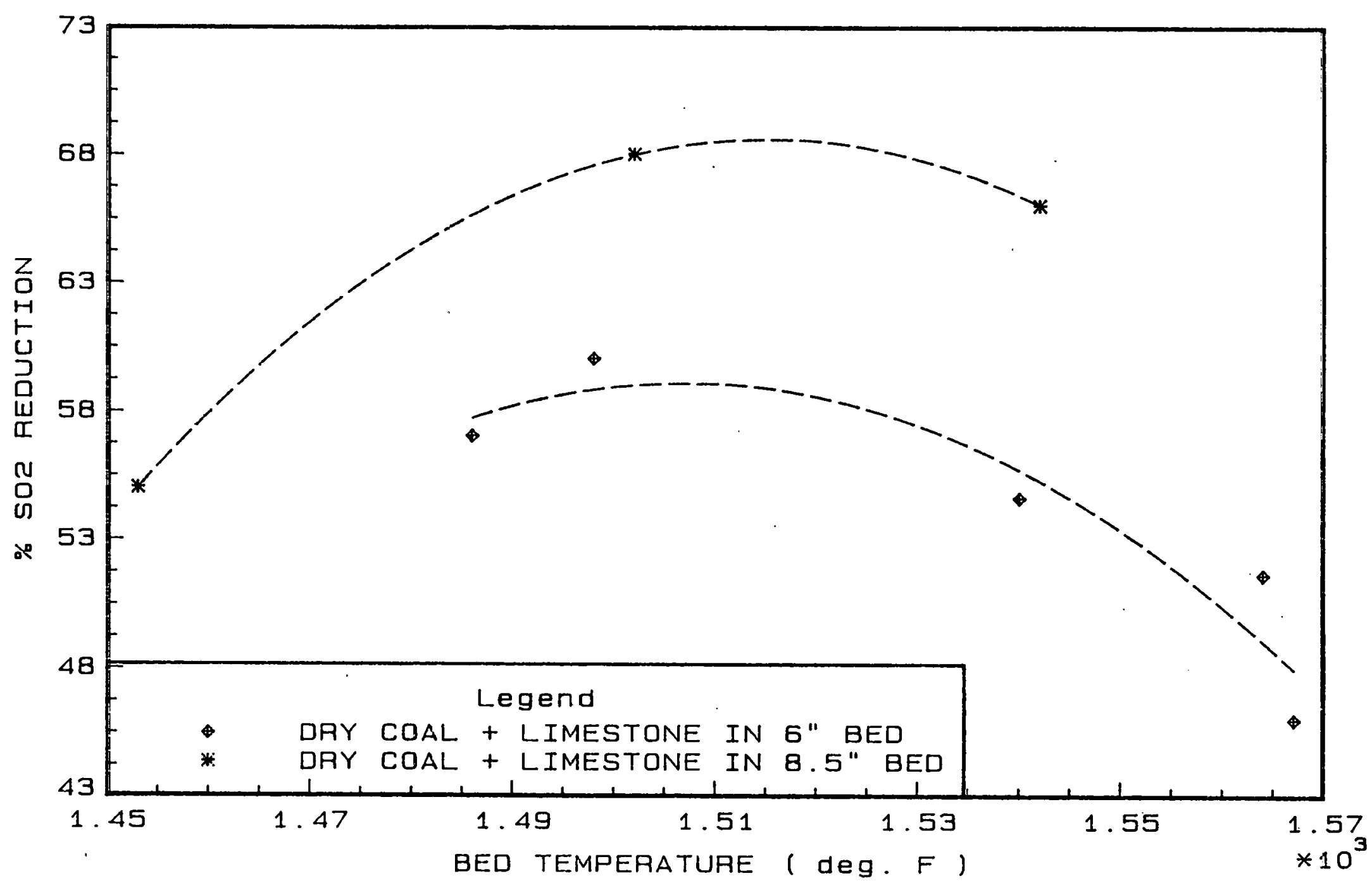


Figure $5 \%$ SULFUR SORPTION VS. BED TEMPERATURE

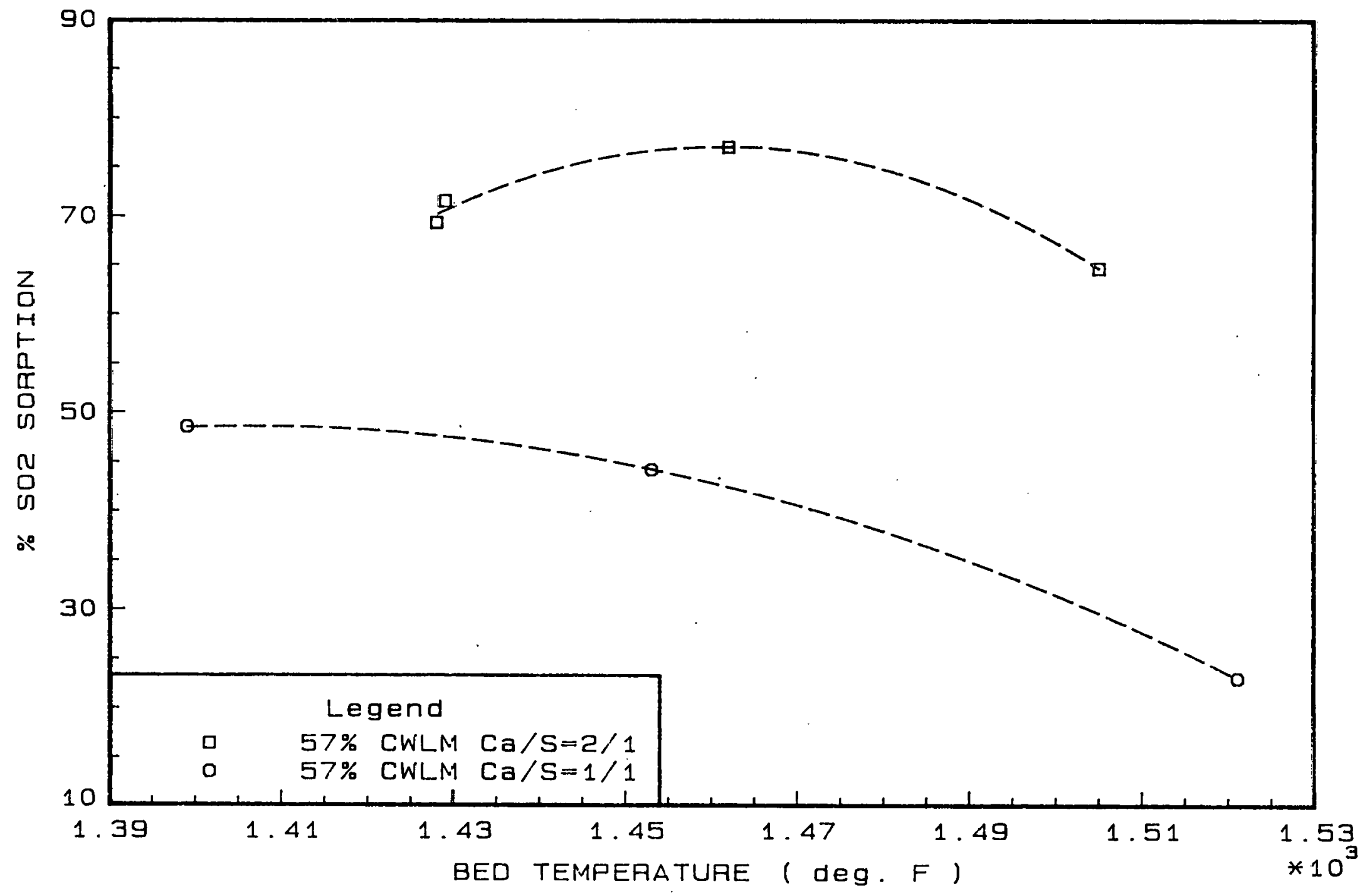

